\title{
A Comprehensive Review on the Effects of COVID-19 Pandemic on Public Urban Spaces
}

\author{
Hourakhsh Ahmad Nia* \\ Faculty of Architecture, Alanya HEP University, Alanya/Antalya, Turkey
}

Received 2021-05-01, accepted 2021-08-13

\section{Keywords}

COVID-19, functional cities, pandemics, smart cities, third places, urban design.

\begin{abstract}
COVID-19, evidently the world's worst pandemic during the last two centuries, has predicated several challenges for urban designers, especially in their bid to find appropriate designing strategies. Even though there are umpteenth studies in the literature that have focused on the different aspects of COVID-19 related pandemics, very scant studies sought to find appropriate mitigating strategies in designing pandemic friendly urban spaces. Thus, through qualitative grounded theory as a main methodological approach, this study hypothesized that the COVID-19 induced pandemic has direct effects on the liveability of public spaces. Accordingly, by developing a comprehensive review of the literature on the environmental and socio-economic effects of the pandemic, this study proposed a comprehensive framework for understanding its side effects and a comprehensive mitigating strategy to deal with it in the short and long term of designing a healthy urban environment.
\end{abstract}

\section{Introduction}

December 2019 was the onset of COVID-19 from Wuhan City of China, which was later confirmed as an international public health emergency by the World Health Organization [1]. This event, from a bird's eye perspective, displays enormous global set-back stemming from huge socioeconomic disruption induced by the pandemic. This has also affected the public urban spaces either directly or indirectly [2].

Alarmingly, despite historical records of pandemics, only a modicum number of literature sources have examined the import of pandemics on cities before the outbreak of COVID-19 [3]. Indeed, erstwhile studies bordering on pandemics are mainly related to urban inequalities and how it impinges on pandemics [4]. The sudden emergence of the COVID-19 and its related issues highlighted the discussion on urban vulnerability and pandemics thusly awakening interest in the subject. The chances for higher occurrences of pandemics are umpteenth in the future, especially with the current wave in the encroachment of natural wildlife habitats and climate change. In the light of this, studies on the dynamics, underpinnings and underlying patterns of pandemics, their impacts, and corresponding mitigating response have suddenly become imperative [5]. Stemming from these, the current wave of pandemics offers opportunities for exploring and understanding how cities respond to pandemics and necessary actions to promote pandemic resilient cities.

Studies that constantly seek to unravel the underlying patterns of the COVID-19 pandemic in urban spaces by shedding more light on the different aspects of this pandemic are the highlights of published research in recent times [6]. Indeed, since the nascent stages of the pandemic, its impact on cities and the awareness it commands have received significant attention. Without a doubt, the pandemic has revived the concerns about cities and their potential vulnerabilities to infectious diseases and pandemics [3].

In this regard, this study by using qualitative grounded theory focuses on the different environmental, social and economic consequences of the pandemic to develop a comprehensive framework that will help urban designers and architects to have an overall understanding of its side effects on people's public life. Qualitative assessment of the related literature will be considered to reach the main 
objectives of the study. Accordingly, the possibility of using smart city technologies to create pandemic resilient and functional cities will be discussed in this article.

\section{Material and Methods}

Stemming from the epistemology of this subject, the qualitative grounded theory approach is considered appropriate for this study. In this regard, qualitative assessment of the related literature has been considered carefully to reach the main objectives of this research. This is to develop the overall framework of understanding the different aspects of the pandemic on people's lives in public urban spaces. Hence, it is considered appropriate to collect related literature on Covid-19 related pandemics on public urban spaces. The study also took a chronological view of pandemics through history to highlight the rapid expansion of diseases in the last two centuries. In this regard, available published literature, reports of governmental and nongovernmental organizations and case studies have been qualitatively evaluated to assess the different aspects of the COVID-19 related pandemic on public urban spaces in order to be able to develop design recommendations for the short term and long-term pandemic resilient urban environment.

\section{Cities and the History of Pandemics}

The city and its experiences of pandemics succinctly show that its history is connected with each other. Cities as an arena of disease contagion and a high possibility for disease expansion have led to deaths in millions through history. Following this, to be able to understand the necessity of studies on pandemics in designing a healthy city, Fig. 1 illustrates the deadliest pandemics through history. It reveals that the number of pandemics sharply increased during the last two centuries. This might be a caveat particularly to urban designers to awake their responsibility in designing pandemic resilient public urban space.

The emergence of epidemics, particularly those that precipitate respiratory disorders, necessitate the closure of public spaces and the isolation of those affected. More often than not, it also impinges on the image of public spaces and cities and transforms them into empty environments. A change in the design approach that integrates environmental health and the form of cities into social thinking is therefore required. With historicists review of pandemics as of the 'Athenian plague' in $430 \mathrm{BC}$ till the 'Black Death' in the 14th century in Europe, insights into the effects and consequences of pandemics on changing designs of cities, the concept of quarantining and zoning laws becomes clearer [7]. Offshoots of these include transformations that result in expanded cities to prevent overcrowding and the radical urban renaissance [8], [9]. Highpoints regarding this include the formation of public squares, parks and walkways in European cities which were early challenges at providing benign public urban spaces [10]. Arguably, the most pronounced implication of the offshoots was the birth of the 'public health' initiatives in the $20^{\text {th }}$ and $19^{\text {th }}$ centuries [11], [7], which took the position that cities are 'unhealthy places' filled with transmittable diseases [12].

A retrospective look at historical developments in the $19^{\text {th }}$ century highlights the wave of unprecedented urbanization that characterize the era as a precipitate of the second industrial revolution. Then, chaos, which was a fall-out of a dense population of humans, interweaved with non-biological but active urban spaces, ambitiously tall buildings, entertainment and developments in railways transport were features that manifested in cities [13]. Thus, lessons from the past have become inevitable in

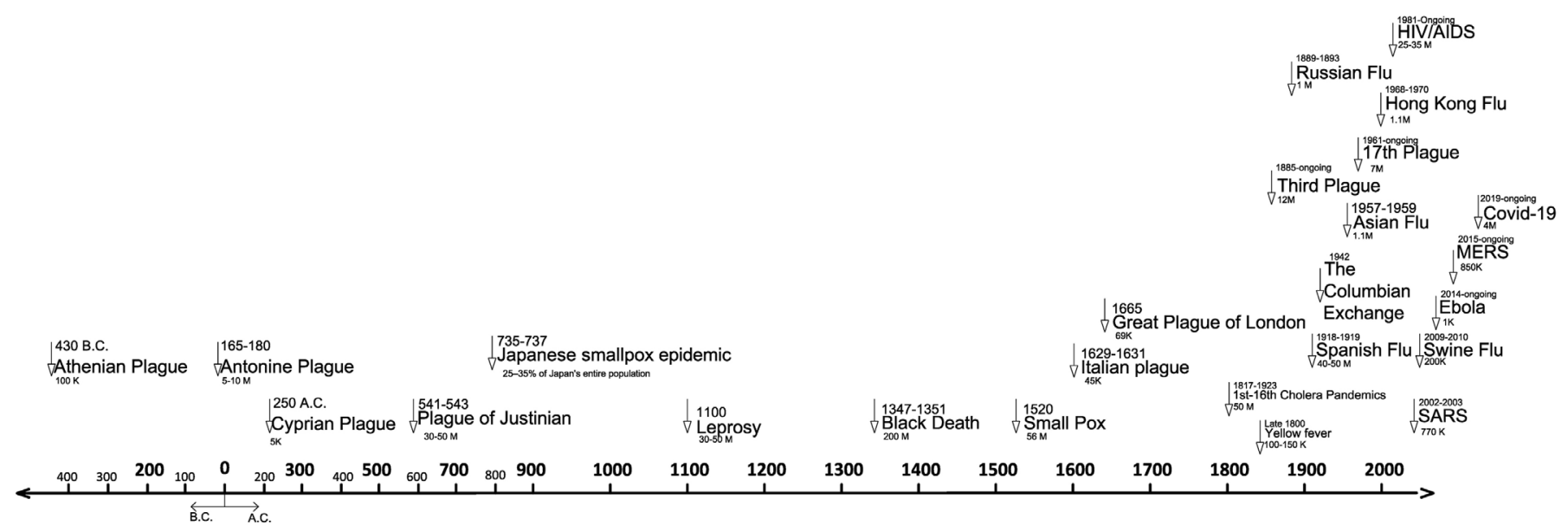

Fig. 1. Pandemics throughout history [Developed by the author]. 
confronting a global epidemic of city origins [14]. As an illustration, it is noteworthy that the spread of cholera was prevented in the 1850s in Paris by controlling population densities in some cities. This was by the establishment of the sewage system and widening the streets and parks [15], [16]. As stated above, cities have been affected by pandemics throughout history; it is noteworthy that each pandemic provided opportunities for urban designers to acquire new skills. In this regard, understanding the socio-cultural and economic consequences of the COVID-19 pandemic will also shed light on designing more functional cities.

\section{Impacts of the Recent COVID-19 on Public Urban Spaces}

In reality, lifestyles, habitats and the use of cities have become convoluted owing to the COVID-19 pandemic emergency. The transformation of private spaces into public because users fled the public domain from fear of infection was instructive. Houses and balconies became offices for work and study providing a lee-way that substitute public for private life. Indeed, the children-teacher relationships which were normally in the physical manifestations have turned virtual through the use of the internet. Adults also started to use the smartphone and smart technologies.

The closure of urban public spaces was one of the more dramatic responses to COVID-19 which impacts the 'third spaces' such as gyms, restaurants, barbershops, bars and cafes [17]. Their closure recalls the social imperatives of these 'third spaces'. Even considering that the lockdown decimates and these places now reopen, the challenges of 'social distancing' steel persist [18]. Thus, the risk of business failure is more domiciled in the third place of cities [19], [20]. Within these limits, it can be projected that the after-effect of the COVID-19 will lead to stricter measures against human-to-human contact between strangers and the idea of social distancing will be more vigorously pursued and intensified. Following these precautions, it is evident that the third places will witness a decline in proportion and number leading to an upsurge in 'safety' but at the expense of 'social intimacy' and therefore be counterproductive. Arguably, left-wing optimists posit otherwise and assert that the developments will give rise to the liberation of more street space for cyclists and pedestrians which are the underpinnings of low carbon economies and green cities [21]. As a matter of fact, at the nascent stage of the epidemic, there was a substantial argument on the need to re-design public spaces and create boulevards to meet up the social distancing criteria.

From the current circumstances, it appears that the norms even after the stay home restrictions have been lifted will not immediately revert to the status quo but to a less rigorous phase of social distancing. During this phase, cities may be required to implement make-shift pedestrianization and street calming projects, following the tenets of tactical urbanism [22]. This suggests that to avoid after-thought and to meet other emerging needs the streets should be re-designed. The take-off of home food delivery and online shopping have lent credence to this suggestion by creating an enormous request for delivery and drop-off space. Street re-designs that are pedestrian-friendly and that enhance active mobility can inevitably reduce physical activity and carbon emission thereby serving to meet up the public health requirements. Overall, the authors believe that the current pandemic is instructive and will motivate urban designers to reconsider the importance of health issues in designing urban spaces. Thus, this study assessed the social, economic and environmental consequences of COVID-19 on urban public space.

\section{COVID-19 Pandemic in Urban Life}

\section{A. Economic Dimensions}

The extant pandemic has inflected our overall understanding of the economic consequences of disasters on cities. As a matter of fact, owing to these lockdowns, many people became jobless. And because of government restrictions on the flow of people in public urban spaces in their bid to control the pandemic, the economic vitality of the urban spaces became endangered. The third places such as the stores, shops and restaurants dis-allowed serving customers. It has also affected the tourism sector and many hotel and shop owners who relied solely on this sector for sustenance became bankrupt. Thus, the professional service sector could not afford to pay their workers' salaries. Likewise, the wholesale and retail sectors faced economic problems and street vendors lost their opportunities at contributing to the economic vitality of cities.

In the majority of the countries such as the USA, UK and India we witnessed that pandemic destroying the traditional use of their urban spaces to generate vitality and economic benevolence. Despite this, it is fair to mention here that each country had its strategy to support its citizens, particularly the vulnerable ones, but because of the extensiveness of the disaster, these supports were inadequate. Conditions in informal settlements and slums were also worsened by the lack of basic infrastructures and medical care such as hospitals and clean water to comply with the handwashing regulations [23].

Overall, reports received from the governments on the effects of the COVID-19 pandemic revealed its impact on the informal and urban sectors with copious reverberations on their welfare, public finance, and inequality. This will strengthen already marked economic and social inequalities as well as increase 'urban poverty', especially on a global 
scale. Nonetheless, it represents a chance to rethink the city, the infrastructures, public services, and other governance structures [24]. Put succinctly, COVID-19 has forced the re-thinking of city living. Urban designers should take the opportunity to reimagine more lively, equitable and interesting post-pandemic cities. In this regard, Chakraborty and Maity (2020) believe that COVID-19 is therapeutic, as it can assist in environmental recovery by reverting damages already incurred through environmental abuse [25].

\section{B. Social Dimensions}

Considering the viral nature of COVID-19, it is imperative to mandate social distancing. Indeed, social distancing became trending and remained a norm in most world countries almost immediately after WHO declared COVID-19 as an epidemic. Social distancing, quarantining or lockdown nourishes anxiety in unhealthy as well as healthy people living in pandemic infested areas [26]. It should be recalled that the social impact of the pandemic impinges on both developed and developing countries. Primarily, the focus of this impact is negative, notwithstanding that there are shreds of evidence that support crisis-induced positive social activities. Most studies have discountenanced this and focused on issues bordering on protracted structural inequalities of societies. From the benefits of hindsight, the impacts of pandemics have been disproportionate with the socioeconomically disadvantaged people and minorities affected the most [27]. They often suffer more as a result of their rather intensive economic difficulties, poor risk management and access to services [4]. In addition, COVID-19 has affected other 'vulnerable' people in urban spaces. This and other inequality concerns question the effectiveness of social distancing by implication of the orders of staying at home for curtailing the feast of the disease.

Eventually, COVID-19 will inflect spatial planning laws and behaviour in public spaces. Social distancing rules and regulations will become more stringent. Eventually, park benches will be marked for appropriate distancing, chairs will be further displaced in cafés, boulevards will be encouraged and streets will transform as pedestrian alleys. Despite these, unneighbourly bonds, as well as family bonds, will be strengthened. More people will likely cycle and walk. The worth of properties and private spaces will rise and inequalities stemming from socioeconomic stratification will deepen. The value of public spaces will decimate and this will be accompanied by the concurrent atrophy of public spaces. Digital technologies for entertainment, shopping and online works will grow rapidly.

\section{Environmental Dimensions}

COVID-19 had many negative and positive effects on cities. On the one hand, it precipitated into a surge of waste. In this regard, copious examples include certain big companies such as McDonald's and Starbucks that have turned away from the more economical water bottles and shopping bags to temporary 'plastic' items such as water bottles, gloves, face masks and cups in their attempt to prevent the spread of the virus. However, there is a wave of scientific belief that the current lockdown increases air quality [28].

In line with this, Zambrano-Monserrate et al. [29] echoed the beneficent consequence of the 'lockdown' on the cities stating that it enhances air quality and reduces sound pollution. It is worthy of note that sound pollution is the outcome of extensive industrial activities which can be counter-productive and damaging to the natural order [30].

Although the fact that the current pandemic leads to some positive environmental effects, urban designers must evaluate its environmental consequences on urban spaces. Sadly, owing to the lockdown, urban space transformed as lost or dead spaces inasmuch as the city without its people are dead spaces. As stated in Table I, urban congestion, high density, longdistance travelling, social gathering, shared vehicles, homelessness and inadequate housing, elevators, public transportation, stores and restaurants are the most obvious environmental factors with a high propensity for transmitting the disease during pandemic. However, these can be abridged with frequent cleaning, appropriate design, sanitizing and proper physical distancing. In this regard, Table I provides a checklist for citizens to upsurge their pliability to the pandemics and other environmental, social and economic consequences of pandemics. It also proposes mitigating strategies to tackle the pandemic in the short and long term.

\section{Functional Cities as a Proposal for the Post-Pandemic Era}

Hitherto, some cities have proved to be quite successful at managing crises such as the COVID-19 pandemic. These cities are referred to in this study as 'functional cities'. These are cities that highlight planning as a functional tool to achieve its optimal capabilities and to create the best conditions for the urban life and the abundant living of its residents. In this scenario, the government has gained the respect of people and the people they trust of the government. This moiety makes crisis management easier and more effective for the government to achieve. The smart city approach of employing modern technology enhances efficient access to services. Moreover, in functional cities governments need to develop a strategy that enables mutual trust between the citizens and the system. For example, in the case of Turkey, all the instructions given by the government have been respected by its citizens and 
implemented successfully [43]. These strategies are important in minimizing the negative effects of COVID-19 on the economic and environmental aspects of public spaces. Aside from these, it is expedient that structures that promote short- and long-term interventions in the bid to control the pandemic should be enacted.

\section{A. Smart Cities}

The transition of communal interactions from the physical manifestations to digitally simulated cyber communities is a spectacle that has received acknowledgements from notable scholars over the years. A typical example was cited by Ewa Rewers, implying in her publication in 2005 that during the advent of the industrial revolution, the agora was transformed into electronic media [31].

Smart cities worldwide are taking advantage of the endless possibilities that can be achieved by the utilization of information and communication technologies (ICTs) to tackle challenges brought on by the COVID-19 pandemic. During the COVID-19 pandemic, the internet, among other ICT applications, gave several people across the globe the opportunity to communicate irrespective of distance, receive necessary information updates frequently and study from the comfort of their home, without being denied access to essential amenities. They also made available a platform that aided the supply of crucial health intelligence, tracking new developments concerning the virus and discovering critical health assets.

Hence, smart cities can play critical and germane roles during the pandemic. Thus, some governments have harnessed smart city hi-tech and other digital data-like mobile devices to track and trace persons infected with COVID-19. One of the countries that has so far achieved control over the spread of the virus is Turkey [43]. Some of the reasons for this are that they were able to come up with a COVID-19 testing kit in less than no time using a smart isolation system. This was achieved by collecting patients' data and then using the QR Video technologies which inform on the status of each registered person. China's success also shows that they rely on technology / hi-tech companies to track the spread of the virus. From these reviews, it is evident that smart cities are better and safer [44].

With the rise in the number of cities and residents, it is only rational to alter the way we design cities to make them safer and better and be ready to face other upcoming challenges. Whereas most of the places around the world make use of social distancing methods to help curb the spread of the disease, it is important to concentrate on the strategies used by successful countries. Their approaches may become necessary in developing post-pandemic functional cities.

\section{B. Street Design Proposals}

Due to major challenges faced in the public health sector in recent years, there have been questions raised on disease prevention mechanisms. There have been various remedies put in place that aim to foster a more desirable public health system. A major remedy is street redesigning which entails providing alternatives for other uses aside the vehicular movement. This includes pedestrians and cyclists in alleys aiming to create more socially sustainable and healthier cities in times of pandemic [32]. It is also imperative to highlight the use of sidewalks in street re-designing. The thrust of this strategy is to provide appropriate setbacks that foster environmental hedonism and pleasure [33]. Using green and natural areas together with smart city strategies in streets of the post-pandemic era will reduce the chances of contamination.

\section{Population Density}

The population density in the cities has been one of the primary issues that affect the spread of viruses. In other words, infection risks apply to the population [34]. In this regard, urban designers need to consider proper planning strategies to face epidemics in a sustained way.

\section{Social Segregation and Physical Distancing}

In his book "The Hidden Dimension" Edward Hall stated that social distance completely depends on behavioural patterns. He identified social distance, personal distance, intimate distance and public distance, then suggested logical spatial measures to each indicator [35]. Throughout literature, it appears that there would be distancing in human interpersonal space at the stretch of $1.5 \mathrm{~m}$ as a result of the outbreak of pandemics. As a result of the extension in social proximity, changes in human behaviour relating to space-use will likely occur. The reverberation effects will modify the use of public benches, promote an emphasis on the interpersonal space and as a result encourage independent social existence.

\section{E. Hygiene, Sanitization, and Ventilation}

COVID-19 affected surfaces is a major means of contracting the virus. This is an environmental health issue of immense concern. This calls for precautionary action like cleaning surfaces such as buses and stations that could be constantly exposed. This level of sanitation has been solely embraced by different nations in varying moods and approaches. Indeed, public transportation staffs are no exception. The mode of their activities in enclosures and administrative buildings is very significant in the control of COVID-19. The potency of this approach is rarely accessed amongst us. This is why 
users should always be informed on safety practices like regular hand sanitizing and avoiding individuals that show possible symptoms during transit.

\section{F. Sustainable Mobility}

The current pandemic revealed strong correlations between urban spaces, mobility, and health [36], [37], thus lending evidence that supports the transport models of cities as a way forward. Strategic planning and detailing are required for pandemic-resilient cities which can successfully combat the risk of infections. This requires the provision of basic access that minimizes infection risk and delivery services during periods of restricted mobility and provides affordable mobility for marginalized households. Walking and bicycling are commonly the most affordable and safest modes. Moreover, this assists in the reduction of social isolation and also improves physical and mental health, so improving walking and bicycling conditions tends to increase resilience.

Measures taken towards sustainable mobility can be very benevolent and lead to a cleaner urban environment [38]. Policies towards advanced land-use planning and sustainable mobility can likewise contribute to an increase in the use of public transit, walking and cycling. Overall, addressing urban mobility is, therefore, an essential issue for post-COVID cities [39].

Moreover, the requirements for social distancing show that public transits cannot perform optimally. Depending on the history, culture and background of societies, this implementation may require more time. Overall, the objective of any program for the post-pandemic mobility era should be to enhance non-motorized mobility.

\section{Integration of the Health Perspective in Designing Cities}

Results of this study reveal that the post-pandemic era should re-think the social-economic and environmental dimensions of functional urban spaces. Hence, this study suggests biological considerations of pandemics in functional cities. Therefore, smart cities approaches should evolve in such a way as to protect urban dwellers from the negative effects of pandemics.

In view of the possibility of transferring the disease via contact with material surfaces already contaminated by an 'infected person', 'touchless technologies' should be advocated [40]. In this regard, voice control, key card swiping and 'face recognition technologies' can be annexed for this purpose [41]. Indeed, the use of alternative control such as smartphones for touch devices such as blinds and elevators or motion sensors for doors should be encouraged [42]. Self-cleaning spaces, especially in commercial restrooms and domestic bathrooms, are an effective means of controlling the virus.

In addition, cities and municipalities can better combat the pernicious effects of pandemics by enhanced transportation sanitation services. Further extension of outdoor sidewalks spaces and more tolerance for restaurant or business owners to use promenades or open spaces not under 'strictly designated' is encouraged. This could ease densification and prove an effective planning solace. All of these can be corroborated by thought-out planning and green landscaping.

Overall, the consideration of social, economic and environmental impacts of the pandemic on urban spaces in view of the suggested theoretical framework reveals

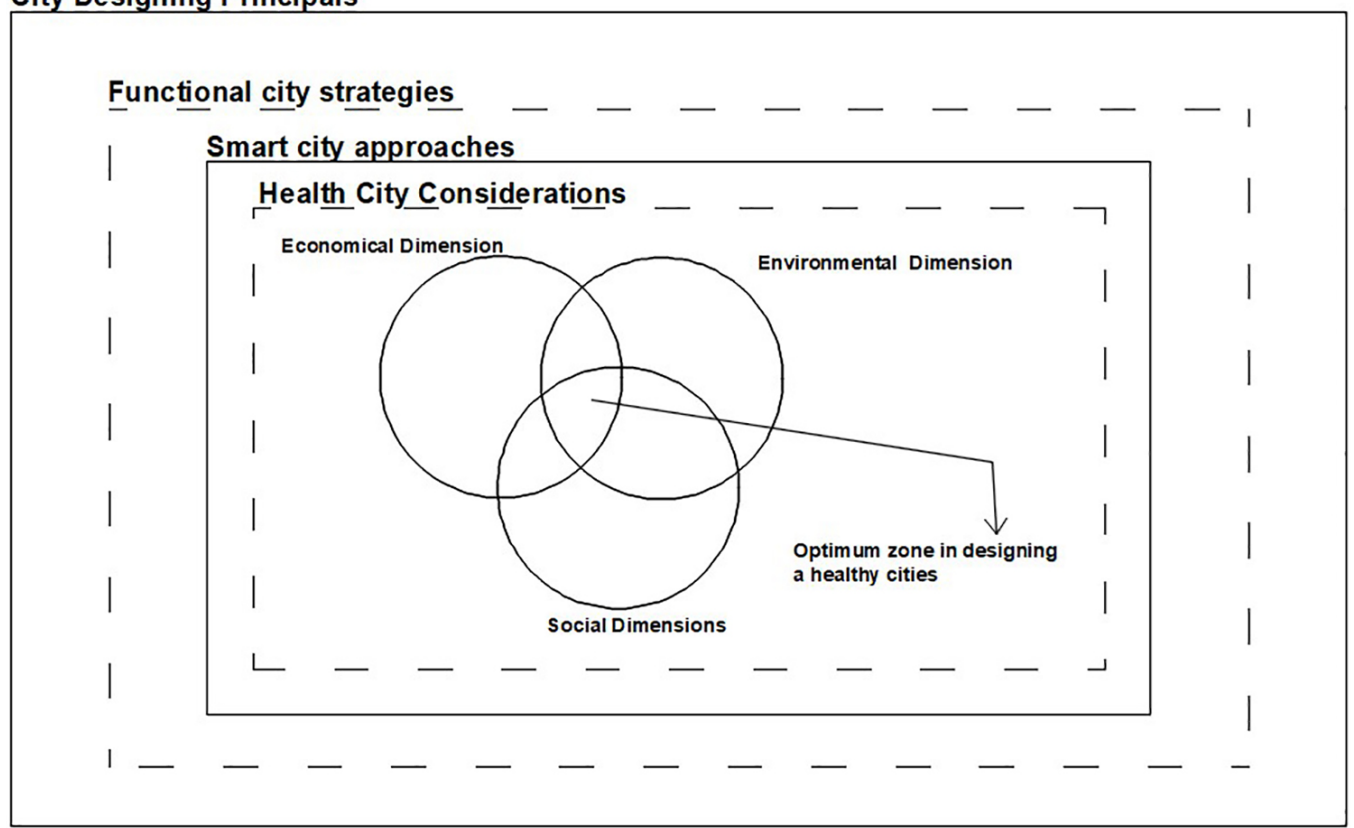

Fig. 2. Optimum zone in designing a functional city [Developed by the author]. 
the blueprint for urban designers in the pursuance of a pandemic resilient environment. City designing strategy is imperative in designing functional cities. In addition, smart city technologies are also germane in designing healthy cities. Figure 2 illustrates that the optimum zone in designing pandemic resilient functional cities is one that simultaneously considers all social, economic and environmental dimensions of urban spaces.

\section{Conclusions}

Cities are shaped by the socio-economic and environmental impacts of pandemics. Chronological analysis of the pandemics through history reveals that during the last 200 years the number of pandemics has increased dramatically. The finding warns urban designers of a high possibility of facing another pandemic in the near future. Accordingly, the study suggested strategies for longand short-term interventions that foster the development of pandemic resilient urban spaces.

The study showed the strong departure between pandemic disasters and other forms of disaster. This is because pandemics threaten the users of public spaces while the other forms affect infrastructures. Moreover, pandemic induced disasters are usually protracted with huge economic consequences, thus mitigation should be mainly concerned with providing economic security. The short-term securities include social distancing while the long term embraces the provision of infrastructures. This is an essential step in the development of functional cities. The pandemic will create the novel framework to re-think the public space, thereby providing a new design vocabulary for re-structuring our public spaces to design pandemic appropriate cities. This study developed the COVID-19 environmental risk factors and mitigating strategies in urban spaces based on its short-term and long-term approaches using the qualitative assessment of the related literature. The following table illustrates the contribution of this study.

As illustrated in Table I, by adopting a methodical and user-friendly layout, functional urban areas become more distinct, efficient and pleasant to live in. It also revealed that the current idea of smart cities might be a reasonable approach to the objectives of functional cities, especially from the post-pandemic design perspectives.

The study also showed that the dense concentration of people in cities provides the ideal condition for the spread of transmissible diseases. It also revealed that the design of pandemic resilient cities requires the simultaneous consideration of socio-economic and environmental imperatives of cities. As a result, smart cities technologies have proved to be an appropriate strategy in the development of functional cities. This

TABLE I

COVID-19 Environmental Risk Factors and Mitigating Strategies in Urban Spaces [Developed by the author]

\begin{tabular}{|c|c|c|}
\hline Environmental risk factors & Mitigating strategies & \\
\hline $\begin{array}{l}\text { - Crowded buildings and sidewalks } \\
\text { - Crowded spaces } \\
\text { - Elevators and public utilities } \\
\text { - Long-distance travelling } \\
\text { - Narrow sidewalks and paths } \\
\text { - Public facilities } \\
\text { - Public transit } \\
\text { - Public vehicle travel } \\
\text { - Social and cultural gatherings } \\
\text { - Stores and restaurants } \\
\text { - Street vendors and homeless people } \\
\text { - Third places }\end{array}$ & Long-term approaches & $\begin{array}{l}\text { - Practicing social distancing } \\
\text { - Business closing and lockdowns } \\
\text { - Citizens respect the hygienic rules } \\
\text { - Contact tracing } \\
\text { - Decreasing unnecessary social and cultural activities } \\
\text { - Increasing the walkability } \\
\text { - Passenger illness check using QR code } \\
\text { - Passenger temperature check } \\
\text { - Regularly sanitation of public spaces and targeted cleaning } \\
\text { - Surface touchless technologies } \\
\text { - Temporary bike lanes } \\
\text { - Using face masks } \\
\text { - Using handwashing and sanitation tools in public urban spaces } \\
\text { - Smart city technology } \\
\text { - Self-cleaning spaces, UV light } \\
\text { - Developing smart city strategies } \\
\text { - Enhancing sanitation of public vehicles } \\
\text { - Slow street program } \\
\text { - Increasing green spaces and pedestrian walkways in cities } \\
\text { - Smart community, industry, homes } \\
\text { - Smart mobility } \\
\text { - Improve walking and bicycling } \\
\text { - Green spaces } \\
\text { - Subsidized bike-sharing program } \\
\text { - Functional urban spaces } \\
\text { - Educating people to trust the system in case of natural disasters } \\
\text { - Promoting hygienic rules } \\
\text { - Face recognition technologies and voice control }\end{array}$ \\
\hline
\end{tabular}


research recommends further studies on the psychological effects of pandemic related lockdowns and the application of green cities in designing pandemic resilient urban spaces. A historical survey of pandemics and how this has impacted cities through history is also suggested for further research.

\section{REFERENCES}

1. Coronavirus disease (COVID-19) pandemic. World Health Organization, Geneva [online]. WHO [cited 15.05.2021]. https://www.who.int/emergencies/diseases/novelcoronavirus-2019

2. Saadat, S., Rawtani, D., Hussain, C. M. Environmental perspective of COVID-19. Science of The Total Environment, vol. 728,2020 , p. 138870

https://doi.org/10.1016/j.scitotenv.2020.138870

3. Matthew, R. A., McDonald, B. Cities under Siege: Urban Planning and the Threat of Infectious Disease. Journal of the American Planning Association, vol. 72, no. 1, 2006, pp. 109-117. https://doi.org/10.1080/01944360608976728

4. Wade, L. An unequal blow. Science, vol. 368, no. 6492, 2020, pp. 700-703. https://doi.org/10.1126/science.368.6492.700

5. Connolly, C., Ali, S. H., Keil, R. On the relationships between COVID-19 and extended urbanization. Dialogues in Human Geography, vol. 10, no. 2, 2020, pp. 213-216. https://doi.org/10.1177/2043820620934209

6. Harapan, H., Itoh, N., Yufika, A., Winardi, W., Keam, S., Te, H., Megawati, D., Hayati, Z., Wagner, A. L., Mudatsir, M. Coronavirus disease 2019 (COVID-19): A literature review. Journal of Infection and Public Health, vol, 13, no. 5, 2020, pp. 667-673. https://doi.org/10.1016/j.jiph.2020.03.019

7. Uwajeh, P., Ezennia, I. Evaluating Staff Perceptions of Supportive Healing Environment in Healthcare Facilities. Journal of Contemporary Urban Affairs, vol. 3, no 1, 2019, pp. 13-25. https://doi.org/10.25034/ijcua.2018.4678

8. Mahoney, E. The Black Death: Bubonic Plague Attacks Europe. New York, NY: Greenhaven Publishing LLC., 2017. 104 p.

9. Hays, J. N. Epidemics and pandemics: their impacts on human history. Goleta: ABC-CLIO, 2005. 500 p.

10. Nieuwenhuijsen, M. J. Urban and transport planning pathways to carbon neutral, liveable and healthy cities; A review of the current evidence. Environment International, vol. 140, 2020, p. 105661. https://doi.org/10.1016/j.envint.2020.105661

11. Kibert, C. J. Sustainable construction: green building design and delivery. Hoboken: John Wiley \& Sons, 2016. 432 p.

12. LePan, N., M. Routley. Visualizing the History of Pandemics. Visual Capitalist, COVID-19. 2020 [online, cited 12.05.2021]. https://www.visualcapitalist.com/history-of-pandemicsdeadliest/

13. Crosby, A. America's Forgotten Pandemic: The Influenza of 1918. Cambridge: Cambridge University Press, 2003. 356 p. https://doi.org/10.1017/CB09780511586576

14. El Helou, M. Shaping the City that Decreases Overweight and Obesity through Healthy Built Environment. Journal of Contemporary Urban Affairs, vol. 3, no. 2, 2019, pp. 16-27. https://doi.org/10.25034/ijcua.2018.4697
15. Harning, L. N. Comparing and Contrasting Social, Political, and Medical Reactions to 19th Century Cholera Epidemics in London and New York City. Honors Theses and Capstones. Durham: University of New Hampshire, 2015. 83 p.

16. Pin, C., Galimberti, D. Making metropolis: innovation and local governance issues in Paris and Milan, in Cities as Political Objects. Cities as Political Objects: Historical Evolution, Analytical Categorisations and Institutional Challenges of Metropolitanisation (A. Cole and R. Payre eds.), Cheltenham: Edward Elgar Publishing Ltd, 2016, Cities series, pp. 197-217.

17. Valsecchi Ribeiro de Souza, J., Marotti de Mello, A., Marx, R., 2019. When Is an Innovative Urban Mobility Business Model Sustainable? A Literature Review and Analysis. Sustainability, vol. 11, no. 6, 2019, pp. 1761.

https://doi.org/10.3390/su11061761

18. Stead, D. Institutional aspects of integrating transport, environment and health policies. Transport Policy, vol. 15, no. 3, 2008, pp. 139-148.

https://doi.org/10.1016/j.tranpol.2007.12.001

19. Louafi, $\mathbf{0}$. The phenomenon of mobility, a development challenge for the city of Algiers. Journal of Contemporary Urban Affairs, vol. 3, no. 2, 2019, pp. 144-155.

https://doi.org/10.25034/ijcua.2018.4711

20. Connolly, C., Keil, R., Ali, S. H. Extended urbanisation and the spatialities of infectious disease: Demographic change, infrastructure and governance. Urban Studies, vol. 58, no. 2, 2020, pp. 245-263.

https://doi.org/10.1177/0042098020910873

21. Roberts, D. How to make a city livable during lockdown. Vox, 22 April 2020. Available online: https://www.vox.com/ cities-and-urbanism/2020/4/13/21218759/coronaviruscities-lockdown-covid-19-brent-toderian

22. Lydon, M., Garcia, A. Tactical Urbanism: Short-term Action for Long-term Change. Washington, D.C.: Island Press, 2015. 256 p. https://doi.org/10.5822/978-1-61091-567-0

23. Biswas, P. P. Skewed urbanisation and the contagion. Economic and Political Weekly. vol. 55, no. 16, 2020, pp. 1315.

24. Google Accounts [online]. Google Surveys [cited 15.03.2021]. https://surveys.google.com/warm-welcome?dest=\%2Fyoursurveys\%3Fcategory\%3Dexample

25. Chakraborty, I., Maity, P. COVID-19 outbreak: Migration, effects on society, global environment and prevention. Science of The Total Environment, vol. 728, 2020, p. 138882. https://doi.org/10.1016/j.scitotenv.2020.138882

26. Zheng, G., Jimba, M., Wakai, S. Exploratory Study on Psychosocial Impact of the Severe Acute Respiratory Syndrome (SARS) Outbreak on Chinese Students Living in Japan. Asia Pacific Journal of Public Health, vol. 17, no. 2, 2005, pp. 124-129.

https://doi.org/10.1177/101053950501700211

27. Duggal, R. Mumbai's struggles with public health crises from plague to COVID-19. Econ. Polit. Wkly. vol. 55, no. 21, 2020, pp. 17-20.

28. Wang, Q., Su, M. A preliminary assessment of the impact of COVID-19 on environment - A case study of China. Science of The Total Environment, vol. 728, 2020, p. 138915. https://doi.org/10.1016/j.scitotenv.2020.138915 
29. Zambrano-Monserrate, M. A., Ruano, M. A., SanchezAlcalde, L. Indirect effects of COVID-19 on the environment. Science of The Total Environment, vol. 728, 2020, p. 138813. https://doi.org/10.1016/j.scitotenv.2020.138813

30. Zambrano-Monserrate, M. A., Ruano, M. A. Does environmental noise affect housing rental prices in developing countries? Evidence from Ecuador. Land Use Policy, vol. 87, 2019, p. 104059. https://doi.org/10.1016/j.landusepol.2019.104059

31. Rewers, E. Post-Polis. Wstęp do filozofii ponowoczesnego miasta [Introduction to the philosophy of the postmodern city]. Kraków: Universitas, 2005. 330 p.

32. Litman, T. Pandemic-Resilient Community Planning. Victoria: Victoria Transport Policy Institute, 2021. 270 p.

33. Rueda, S. Superblocks for the Design of New Cities and Renovation of Existing Ones: Barcelona's Case. Integrating Human Health into Urban and Transport Planning (Nieuwenhuijsen M., Khreis H. eds.), Berlin: Springer, 2019, pp.135-153. https://doi.org/10.1007/978-3-319-74983-9_8

34. Gandy, M. The Paris Sewers and the Rationalization of Urban Space. Transactions of the Institute of British Geographers, vol. 24, no. 1, 1999, pp. 23-44.

https://doi.org/10.1111/j.0020-2754.1999.00023.x

35. Hall, E.T. Ukryty wymiar. Warszawa: Muza SA, 2001. 275 p.

36. Honey-Rosés, J., Anguelovski, I., Chireh, V. K., Daher, C., Konijnendijk van den Bosch, C., Litt, J. S., Mawani, V., McCall, M. K., Orellana, A., Oscilowicz, E., Sanchez, U., Senbel, M., Tan, X., Villagomez, E., Zapata, O., Nieuwenhuijsen, M. J. The impact of COVID-19 on public space: an early review of the emerging questions - design, perceptions and inequities. Cities \& Health, Special Issue: COVID-19, 2020, pp. 1-17.

https://doi.org/10.1080/23748834.2020.1780074

37. Von Schönfeld, K. C., Bertolini, L. Urban Streets between Public Space and Mobility. Transportation Research Procedia, vol. 19, 2016, pp. 300-302.

https://doi.org/10.1016/j.trpro.2016.12.089

38. Hickman, R., Banister, D. Transport, Climate Change and the City. Routledge: New York, 2014.400 p. https://doi.org/10.4324/9780203074435

39. Batty, M. The Coronavirus crisis: What will the postpandemic city look like? Environment and Planning B: Urban Analytics and City Science, vol. 47, no. 4, 2020, pp. 547-552. https://doi.org/10.1177/2399808320926912

40. Van Doremalen, N., Bushmaker, T., Morris, D. H., Holbrook, M. G., Gamble, A., Williamson, B. N., Tamin, A., Harcourt, J. L., Thornburg, N. J., Gerber, S. I., LloydSmith, J. O., de Wit, E., Munster, V. J. Aerosol and Surface Stability of SARS-CoV-2 as Compared with SARS-CoV-1. New England Journal of Medicine, vol. 382, 2020, pp. 1564-1567. https://doi.org/10.1056/nejmc2004973

41. Lippe-McGrow, J. The Future of Design after COVID-19. 2021 [online]. Departures [cited 8.01.2021]. https://www. departures.com/lifestyle/architecture/architects-predictfuture-of-design

42. Calzada, I. Book Review: Smart City Citizenship. Journal of Contemporary Urban Affairs, vol. 5, no. 1, 2021, pp. 113-118. https://doi.org/10.25034/ijcua.2021.v5n1-7
43. Ahsan, M. M. Strategic decisions on urban built environment to pandemics in Turkey: Lessons from COVID-19. Journal of Urban Management, vol. 9, no. 3, 2020, pp. 281-285. https://doi.org/10.1016/j.jum.2020.07.001

44. Liu, L. Emerging study on the transmission of the Novel Coronavirus (COVID-19) from urban perspective: Evidence from China. Cities, vol. 103, 2020, p. 102759. https://doi.org/10.1016/j.cities.2020.102759

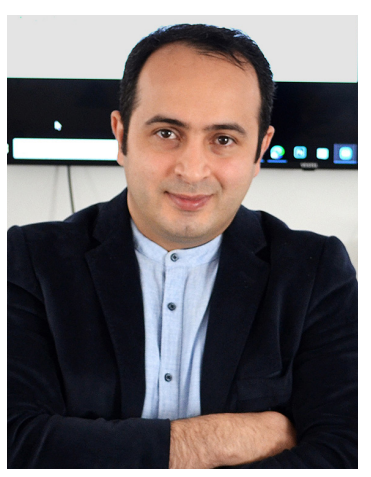

Hourakhsh Ahmad Nia (born 1985) obtained a BA degree in Architecture from A.I. University in 2008. He also received his $\mathrm{PhD}$ from the Eastern Mediterranean University. Currently, he is an Assistant Professor at Alanya HEP University. His main area of expertise is "Aesthetics in Architecture and urbanism". He has been Head of the Department of Architecture and Interior Architecture at Girne American University. He is the founder and Editor in Chief of the Journal of Contemporary Urban affairs and Chairman of the annual ICCAUA international conference series. For 13 years he has been a researcher in the field of architecture and urbanism and is the author of more than 25 scientific articles, 2 books, 1 book chapter. He was also the editor of 6 scientific books. His study mostly covers interdisciplinary studies in humanities and social sciences particularly on the interrelations of aesthetics in architecture and urban design, housing and sustainable urban conservation. He is a member of editorial board of international journals "Town and Regional Planning", "A+Arch Design International Journal of Architecture and Design", "Art and Architecture Studies" and the international advisory board of Space Independent Academic Platform.

\section{Contact Data}

\section{Hourakhsh Ahmad Nia}

Faculty of Architecture, Alanya HEP University, Alanya/Antalya, Turkey E-mail: hourakhshahmadnia@ahep.edu.tr Tel: +905061899966 ORCID iD: https://orcid.org/0000-0002-1083-280X Web of Science ResearcherID: AAH-6918-2019 Scopus Author ID: 57195596077 